\title{
Effects of High Stocking Density on the Expressions of Stress and Lipid Metabolism Associated Genes in the Liver of Chicken
}

\author{
Young Sook An, Jeong Geun Park, In Surk Jang, Sea Hwan Sohn and Yang Soo Moon*
}

Department of Animal Science \& Biotechnology, Gyeongnam National University of Science \& Technology, Jinju 660-758, Korea

Received October 23, 2012 /Revised December 11, 2012 /Accepted December 11, 2012

\begin{abstract}
The effect of high stocking density (HSD) on the expression of stress and lipid metabolism associated genes in the liver of broiler chickens was examined by chicken genome array analysis. The chickens in a control group were randomly assigned to a $495 \mathrm{~cm}^{2} /$ bird stocking density, whereas the chickens in a HSD group were arranged in a $245 \mathrm{~cm}^{2} /$ bird stocking density with feeding ad libitum for 35 days. The chickens assigned to the HSD group had a significantly lower body weight, weight gain, and feed intake compared with those of the control group $(p<0.05)$. The mortality of chickens was higher in the HSD group than in the control group. The microarray analysis indicated up-regulation of stress associated genes such as HMGCR, HSP90a, HSPA5 (GRP78/Bip), DNAJC3 and ATF4, and down-regulation of interferon- $\gamma$ and PDCD4 genes. The endoplasmic reticulum stress associated genes, HSPA5 (GRP78/Bip), DNAJC3 and ATF4, were highly expressed in the HSD group. The genes, ACSL5, TMEM195 and ELOVL6, involved in fatty acid synthesis, were elevated in the HSD group. The genes, ACAA1, ACOX1, EHHADH, LOC423347 and CPT1A, related to fatty acid oxidation, were also activated in the HSD group. These results suggest that a HSD rearing system stimulates the genes associated with fatty acid synthesis as well as fatty acid oxidation in the liver of broiler chickens.
\end{abstract}

Key words : Chicken, high stocking density, stress, microarray, gene expression

\section{서 론}

집약적 사양시스템으로 대표되는 최근의 닭 산업은 여러 가지 스트레스 요인들이 닭에게 발생함으로서 심각한 도전 을 받고 있다. 미래 동물산업은 건강한 가축의 생산과 더불 어 동물복지를 고려한 사양체계로 전환되어야 지속 가능한 산업으로 살아남을 수 있다. 이런 측면에서 유럽에서는 동물 복지정책에 따라 스트레스 요인으로 알려진 케이지 사육에 서 생산된 계란의 판매 금지 및 사료첨가제용 항생제 사용 금지 등과 같은 동물복지와 연관된 다양한 연구를 바탕으로 닭의 육종 및 생산체제의 변화를 모색하고 있다. 스트레스는 다양한 생리적 기작에 영향을 주어 가축의 생산성을 감소시 키는데 스트레스 단일 요인만으로 축산업에서 연간 천문학 적인 경제적 손실을 초래하는 것으로 추정되고 있다. 닭에서 대표적인 스트레스 요인에는 밀폐된 사양 공간에 의한 높은 환경온도와 암모니아 발생, 좁은 공간에서의 밀집사양, 그리 고 밀집사양에 인한 약화된 면역 등을 들 수 있다[7]. 이러한

\footnotetext{
*Corresponding author

Tel : +82-55-751-3262, Fax : +82-55-751-3267

E-mail : ysmoon@gntech.ac.kr

This is an Open-Access article distributed under the terms of the Creative Commons Attribution Non-Commercial License (http://creativecommons.org/licenses/by-nc/3.0) which permits unrestricted non-commercial use, distribution, and reproduction in any medium, provided the original work is properly cited.
}

스트레스 요인들은 동물의 주요 생리적 반응에 영향을 주며, 그 대표적인 것이 생존에 필요한 성장, 항상성유지 등에 이 용하는 것 보다 지방축적 등과 같은 방향으로 에너지의 재분 배를 야기한다[20]. 포유동물의 경우 스트레스를 받게 되면 장간막이나 복부에 지방을 축적하게 된다 $[4,21]$. 닭의 경우 스트레스에 의해 증체량과 사료효율 감소가 보고되었으며 $[9,29]$, 이와 같은 결과는 닭의 골격근 발달저하와 지방축적 증가를 유발한다고 하였다[9,12]. 닭에서 스트레스와 연관된 연구는 고온에 단시간[16,28] 또는 장시간[1,2] 노출된 환경에 서 스트레스에 반응하는 정도를 간 또는 골격근에서 지질과 산화, 항산화효소의 활성 등을 보고한 것이다. 닭에게 장시간 스트레스를 유발하기 위하여 corticosterone을 사료에 첨가하 여 2주간 브로일러에 급여한 후 스트레스에 의한 산화적 손 상을 보고하기도 하였다[17]. 최근에 닭에서 스트레스와 지 놈 전사체 수준(global gene expression)의 유전자발현에 대 한 연구가 보고되고 있다. 브로일러에서 장기간 고온에 노출 된 경우 간과 근육조직에서 지놈 전사체에 미치는 영향을 보 고하였고[15], 브로일러의 출하시 사료절식과, 포획 및 운반 에 따른 지놈 전사체 발현을 간에서 조사 보고하였다[25]. 그 러나 현재까지 동물복지 측면에서 $\mathrm{EU}$ 를 중심으로 법적 규제 대상이 되고 있는 사육 밀도에 따른 가금의 스트레스 분석을 유전체 수준의 유전자 발현을 보고한 연구는 없는 실정이다. 따라서 본 연구는 고밀도 사양체계가 브로일러에서 간의 지 놈 전사체에 어떤 영향을 미치는지 스트레스와 지방대사 연 
관 유전자들을 중심으로 조사하였다.

\section{재료 및 방법}

\section{공시동물 및 시험설계}

본 시험에 공시된 동물은 육용계 수컷 1일령 Ross종 162 수 를 (주)올품에서 구입하여 2일간 적응 기간을 거쳐 3 일령에 본 시험에 이용하였다. 공시된 시험동물은 무작위로 선별하여 대조군(Control, 표준밀도)과 고밀도군(High stocking denssity, HSD; 고밀도) 으로 배치하여 본 대학교 종합농장 동물사 육장에서 5 주 동안 케이지 사육을 실시하였다. 대조군 54수의 사육밀도는 $495 \mathrm{~cm}^{2}$ /수(닭 사육시설 소요면적 농림부 고시 제2004-89호에 준함), 고밀도군 108 수는 $245 \mathrm{~cm}^{2} /$ 수의 사육밀 도를 유지하였다. 점등은 전 사양기간 동안 24 시간 종일 전등 을 실시하였고, 계사온도는 일령별로 $32^{\circ} \mathrm{C}$ 에서 $22^{\circ} \mathrm{C}$ 까지 본 대학의 육계 사육실 온도관리 프로그램에 따라 조절하였다.

\section{체중, 사료섭취량 및 사료요구율}

사양시험 동안 사양성적(성장 및 증체율, 사료섭취량 및 사 료요구율) 및 폐사율을 조사하였다. 사료섭취량, 체중 및 사료 요구율은 시험개시와 종료(35일령)시에 측정하였다. 사료요구 율은 시험기간 중 평균 사료섭취량을 평균체중 증가량으로
나누어 계산하였다.

RNA 분리 및 real time PCR

사양시험 종료 후 각 시험구당 평균체중에 가까운 8 수씩을 처리별로 선정하여 간조직을 채취하여 액체질소에 급속 냉동 하였다. 분석항목으로는 간에서 전사체 발현(global gene expression) 분석(Affymetrix Chicken Genome Array X, Affymetrix, Inc., Santa Clara, USA)과 real-time RT-PCR을 이용하여 microarray 발현 유전자들의 검증에 이용하였다. 각 처리군의 공시동물의 조직으로부터 RNeasy kit (Qiagen, Hilden, Germany)을 이용하여 total RNA를 추출하였다. cDNA 합성은 Improm-II Reverse Transcription System (Promega, Fitchburg, USA)를 이용하여 cDNA를 합성하였다.

Real-time PCR은 MyiQ (Bio-Rad, Herculus, USA)을 이용 하여 시행하였다. Real-time PCR을 위한 primer의 정보는 Table 1에 제시하였다. PCR 반응물은 cDNA (10 ng) $5 \mu \mathrm{l}$, primer (5 pmole)는 각각 $0.5 \mu \mathrm{l}$, SYBR Green (Bio-Rad) 10 $\mu \mathrm{l}, \mathrm{ddH}_{2} \mathrm{O} 4 \mu \mathrm{l}$ 를 넣어 총 $20 \mu \mathrm{l}$ 가 되도록 혼합하고 $95^{\circ} \mathrm{C} 3$ 분 간 최초 변성을 시킨 다음 $95^{\circ} \mathrm{C} 15$ 초간 변성, $60^{\circ} \mathrm{C}$ 에서 15 초 간 접합, $72^{\circ} \mathrm{C} 40$ 초간 확장과정을 40 회 반복하였다. 그리고 $94^{\circ} \mathrm{C} 1$ 분간 재 접합 과정을 거친 후 $55^{\circ} \mathrm{C}$ 에서 1 분간 재 확장 과정을 실시하였다. 마지막으로 $55^{\circ} \mathrm{C}$ 에서 $0.5^{\circ} \mathrm{C}$ 씩 상승시켜

Table 1. Primers used to analyze gene expression by real-time RT-PCR

\begin{tabular}{|c|c|c|c|}
\hline Genes & Primer sequences $\left(5^{\prime}-3^{\prime}\right)$ & Size of products $(\mathrm{bp})$ & Accession numbers (GenBank) \\
\hline HSP90a & $\begin{array}{l}\text { Forward: ggagaagttaccaagcgatt } \\
\text { Reverse: cagaagatgaagaagagaagaaga }\end{array}$ & 133 & NM001109785 \\
\hline HSP70 & $\begin{array}{l}\text { Forward: tcctctgctttgtatttctctg } \\
\text { Reverse: atgctaatggtatcctgaacg }\end{array}$ & 145 & J02579 \\
\hline DNAJA3 & $\begin{array}{l}\text { Forward: tgaaggatgtcagtcagtaac } \\
\text { Reverse: ttctgtatcacgatggttgtt }\end{array}$ & 87 & XM414967 \\
\hline DNAJB9 & $\begin{array}{l}\text { Forward: tgaagtgattgattcttgtcatct } \\
\text { Reverse: tacgcataaacgcctcct }\end{array}$ & 117 & NM001030735 \\
\hline ACOX1 & $\begin{array}{l}\text { Forward: gcaagtcgtaagtcaatgtt } \\
\text { Reverse: acaatcccaaccgtagtg }\end{array}$ & 101 & NM001006205 \\
\hline SCD & $\begin{array}{l}\text { Forward: agcaaactggtagcattatca } \\
\text { Reverse: tctccetttctccttccc }\end{array}$ & 89 & NM204890 \\
\hline SREBP1 & $\begin{array}{l}\text { Forward: gatggtcgcagtggctgt } \\
\text { Reverse: ggctccccgtagacaaaga }\end{array}$ & 97 & AY029224 \\
\hline FASN & $\begin{array}{l}\text { Forward: ttcgtgttaccgcctcag } \\
\text { Reverse: ttcccactgcctgcttag }\end{array}$ & 91 & NM205155 \\
\hline FABP4 & $\begin{array}{l}\text { Forward: atggcaaagagactgttatcaa } \\
\text { Reverse: tgaagacggcttcctcat }\end{array}$ & 118 & NM204290 \\
\hline XBP1 & $\begin{array}{l}\text { Forward: tctgctggatgctggtag } \\
\text { Reverse: aggtatggtcagtgtcaaga }\end{array}$ & 89 & NM001006192 \\
\hline ATF4 & $\begin{array}{l}\text { Forward: agtggatgttctggaaggt } \\
\text { Reverse: ctctttctctgacttggtgat }\end{array}$ & 76 & AB013138 \\
\hline RPL27 & $\begin{array}{l}\text { Forward: cagcaatgggcaagaaga } \\
\text { Reverse: gcatcaggtggttgtagtt }\end{array}$ & 81 & NM205337 \\
\hline
\end{tabular}


형광접합물질인 SYBR Green이 떨어져 나오는 마지막 과정 을 수행하였다. 유전자 발현의 상대적 발현양은 $2^{-\Delta \Delta \mathrm{Ct}}$ 방법 을 이용하였다[18].

\section{Microarray 분석}

표준사양군과 고밀도 사양군의 시험동물의 간에서 RNeasy kit (Qiagen)으로 추출한 total RNA는 DNALINK, INC (Seoul, Korea)에 의뢰하여 Affymetrix Chicken Genome Array X (Affymetrix, Inc.)로 microarray (Affymetrix GeneChip Scanner 3000 7G)를 실시하였다. 같은 처리구의 total RNA는 동일량을 각각 취하여 합한 다음 microarray 시료 로 이용하였다[15].

\section{통계분석}

본 시험에서 얻어진 결과는 평균표푸ㄴㅜㅗ차로 표시하였다. 통계분석은 Proc GLM을 이용하여 분산분석을 하였으며[22], 대조구와 처리구간 유의성 검정은 t-test를 이용하여 분석하 였다.

\section{결과 및 고찰}

\section{고밀도 사육에 따른 사양시험 성적 및 폐사율}

사육밀도(대조군; $495 \mathrm{~cm}^{2} /$ 수, 고밀도군; $245 \mathrm{~cm}^{2} /$ 수)에 따 른 육계사양시험에서 증체량, 사료섭취량, 사료요구율을 조사 한 결과는 Table 2에 제시한 바와 같다. 35일 동안 사양 시험한 결과, 대조구와 비교하여 고밀도(HSD) 사양 육계에서 체중, 증체량, 사료섭취량이 유의적 $(p<0.05)$ 으로 감소되는 것으로 나타났다. 폐사율은 $\mathrm{HSD}$ 에서 $15.4 \%$ 로서 대조군(3.7\%)에 비해 폐사율이 현저히 높은 것으로 관찰되었다. 이러한 결과는 본 실험에서 스트레스 요인으로 처리된 높은 사육밀도가 증체량, 사료섭취량 및 폐사율에 영향을 주었으며, 고밀도 사양에 의 해 육계에 스트레스가 유발되었음을 확인하였다. 이는 고온 스트레스에 만성적으로 노출된 육계 $\left(32-34^{\circ} \mathrm{C}\right)$ 에서 증체량, 사 료섭취량, 사료효율이 감소했다는 보고[1,19]와 유사함을 보여 주었다.

\section{고밀도 사양에 따른 유전체 발현 분석}

육계에서 고밀도사육이 유전체의 발현에 미치는 영향을 관 찰하고자 고밀도와 표준밀도에서 사육된 35일령 육계의 간에 서 total RNA를 추출한 다음 mRNA microarray 분석을 실시 하였다. 처리에 따른 유전자 발현차이(DEG, differentially expressed gene)를 보면, 대조구 대비 2 배 이상 유전자의 발현이 증가한 유전자의 수는 602개 였으며, 발현이 감소한 유전자의 수는 942 개로, 처리에 따른 총 DEG는 1,544 개로 이는 현재 알려진 닭의 총 전사체(RNA transcripts) 32,773 개의 $4.7 \%$ 에 해당된다. $\mathrm{DEG}$ 의 기준을 1.5 배로 낮출 경우, 처리에 의해 증가 된 유전자 수는 1,878 개, 감소된 유전자 수는 2,380 개로 증가 하게 되어 총 전사체 대비 $13.1 \%$ 로 고밀도 사양이 유전체의 전사에 상당한 영향을 미치고 있음을 보여 주었다.

\section{사육 밀도에 따른 간에서 스트레스 관련 유전자의 발현 비교분석}

육계의 사육밀도에 따른 스트레스관련 유전자의 발현을 살펴 본 결과 HMGCR, HSP90a, HSPA5 (GRP78/Bip), DNAJC3, ATF4 등과 같은 단백질은 증가 하였으며, interferon- $\gamma$, PDCD4 등은 감소하였다(Table 3, 4). HMGCR은 HSP 단백질 들(HSP70, HSP90)과 함께 열 스트레스에 매우 민감한 단백질 로 잘 알려져 있다 $[5,27,30]$. HMGCR은 콜레스테롤 생합성의 주요 효소이고, 콜레스테롤은 스트레스 마커로 이용되는 cortisol의 구성성분이기도 하다[10]. 따라서 스트레스 연관 동물 시험의 연구결과에서 대부분의 경우 HMGCR은 민감하게 반 응하여 스트레스 마커로서 잘 활용되고 있음을 알 수 있다. 본 연구에서도 고밀도 사양체계에서 이 유전자의 발현이 표준 사양에 비하여 약 2.6 배 증가하였음을 볼 수 있었다. HSP90a 의 경우 2.1배 유전자의 발현 증가를 보였으나, HSP70은 microarray분석에서 확인 할 수 없었다. PDCD4 (Programmed cell death protein 4)은 포유동물에서 tumor cell의 발달을 억 제하고 세포자살를 유도하는 것으로 알려져 있지만[13], 닭에 서 이 유전자를 적출(knock-out)한 시험에서 DNA의 손상을 유도하는 것으로 보아[26], 밀사에 의한 PDCD4의 발현 감소

Table 2. The effects of high stocking density (HSD) on the performance and mortality in broiler chickens

\begin{tabular}{lccc}
\hline \multicolumn{1}{c}{ Items } & \multicolumn{3}{c}{ Treatment } \\
\cline { 2 - 4 } & Control & HSD & -value \\
\hline Initial BW (g, d3) & $44.36 \pm 0.17$ & $44.40 \pm 0.04$ & 0.858 \\
\hline Final BW (g, d35) & $1690.55 \pm 36.38^{*}$ & $1478.43 \pm 41.20$ & 0.003 \\
Total gain (g) & $1646.67 \pm 36.38^{*}$ & $1434.03 \pm 41.20$ & 0.003 \\
TotalFeed intake & $2531.63 \pm 56.06^{*}$ & $2310.76 \pm 26.95$ & 0.005 \\
Total FCR & $1.54 \pm 0.02$ & $1.62 \pm 0.06$ & 0.226 \\
\hline Mortality, No (\%) & $2(3.7 \%)$ & $17(15.7 \%)$ & \\
\hline
\end{tabular}

Mean \pm SE $(n=6)$.

BW: body eight, HSD: High stocking density, FCR:Feed conversion rate 
는 tumor cell의 증가 가능성과 세포의 DNA 손상[27]을 유도 할 수 있음을 보여 주었다. Interferone- $\gamma$ 의 발현 감소는 바이 러스나 세균의 침투로부터 숙주동물을 방어하기 위한 면역체 계 약화로 이어질 수 있다[23]. HSPA5 (GRP78/Bip), DNAJC3 그리고 ATF4은 endoplasmic reticulum (ER) stress 관련 마커 유전자로 잘 알려져 있다[24]. 본 연구에서도 이들 유전자들은 고밀도 사양군에서 유전자의 발현이 2-3배 증가함을 볼 수 있 었다. 이는 식이성 포화지방산이나 콜레스테롤등에 의해 유도 되는 ER stress [6]가 고밀도 사양체계에서도 발생 할 수 있음 을 알 수 있다. ER stress는 단백질형성이 이루어지는 소포체 내에서 일어나는 unfolded protein response (UPR) 현상으로 알려져 있으며, 포유동물에서 비만, 당뇨, 인슐린 저항성 및 염증반응 등을 유발하는 것으로 알려져 있다[8]. 따라서 육계 의 고밀도 사양체계는 외형적으로 사양성적의 감소도 일어나 지만 동물의 분자 수준(DNA), 세포 수준(ER stress), 면역체계
에도 불리한 환경이 될 수 있음을 보여 주었다.

사육 밀도 스트레스에 따른 간에서 지방대사 관련 유전자의 발현 비교분석

대조구와 $\mathrm{HSD}$ 의 비교에서 유전자의 차이가 2 배 이상인 유 전자중 지방대사 및 스트레스 연관 유전자들의 발현 증감을 Table 3과 4에 제시하였다. 육계에서 밀사에 의한 스트레스가 간의 지방대사 중에서 지방의 합성과 지방산산화에 영향을 미치고 있음을 알 수 있었다. Table 3에 제시된 바와 같이 지방 산 합성에 관여하는 효소들(ACSL5, TMEM195, ELOVL6)의 유전자 발현증가와 지방산산화( $\beta$-oxidatin)에 관여하는 효소 들(ACAA1, ACOX1, EHHADH, LOC423347, CPT1A)의 RNA 발현 증가를 볼 수 있었다. Phospholipid의 생합성에 관여하는 효소(AGPAT4, AGPAT6)의 발현과 불포화지방산 생성을 위한 효소(SCD, stearoyl-CoA desaturase)의 발현 감

Table 3. Information of the up-regulated genes on lipid metabolism and stress

\begin{tabular}{|c|c|c|c|c|}
\hline Accession no. & Gene symbol & Gene function & $\begin{array}{l}\text { Log2 } \\
\text { ratio }\end{array}$ & $\begin{array}{c}\text { Fold } \\
\text { change }\end{array}$ \\
\hline \multicolumn{5}{|c|}{ Lipid metabolism } \\
\hline NM_001197288 & ACAA1 & acetyl-Coenzyme A acyltransferase 1 & 2.89 & 7.43 \\
\hline NM_001031237 & ACSL5 & acyl-CoA synthetase long-chain family member 5 & 1.39 & 2.62 \\
\hline NM_001006205 & ACOX1 & acyl-CoA oxidase 1 , palmitoyl & 1.38 & 2.60 \\
\hline NM_001012898 & CPT1A & carnitine palmitoyltransferase 1A (liver) & 1.14 & 2.20 \\
\hline XM_422690 & EHHADH & enoyl-Coenzyme A, hydratase/3-hydroxyacyl Coenzyme A dehydrogenase & 1.13 & 2.19 \\
\hline XM_420004 & HADHB & $\begin{array}{l}\text { hydroxyacyl-Coenzyme A dehydrogenase/3-ketoacyl-Coenzyme A thiolase/enoyl } \\
\text {-Coenzyme A hydratase }\end{array}$ & 1.04 & 2.05 \\
\hline XM_001235269 & PLA2G12A & Phospholipase A2, group XIIA & 1.11 & 2.16 \\
\hline XM_001234990 & LOC423347 & similar to acetyl-CoA synthetase 2-like & 1.08 & 2.11 \\
\hline XM_417342 & ACSS2 & acyl-CoA synthetase short-chain family member 2 & 1.06 & 2.08 \\
\hline XM_001235520 & TMEM195 & transmembrane protein 195 & 3.21 & 9.24 \\
\hline NM_001031539 & ELOVL6 & ELOVL family member 6 , elongation of long chain fatty acids & 1.09 & 2.13 \\
\hline NM_001044633 & $\mathrm{APOB}$ & apolipoprotein B (including $\mathrm{Ag}(\mathrm{x})$ antigen) & 1.33 & 2.52 \\
\hline NM_001031420 & ADFP & adipose differentiation-related protein & 1.30 & 2.47 \\
\hline NM_001039294 & FDFT1 & farnesyl-diphosphate farnesyltransferase 1 & 2.38 & 5.19 \\
\hline NM_204593 & NR0B1 & nuclear receptor subfamily 0 , group $B$, member 1 & 2.06 & 4.17 \\
\hline NM_001031505 & PTDSS1 & phosphatidylserine synthase 1 & 1.86 & 3.62 \\
\hline NM_204485 & HMGCR & 3-hydroxy-3-methylglutaryl-Coenzyme A reductase & 1.40 & 2.64 \\
\hline NM_204995 & ALDH1A2 & aldehyde dehydrogenase 1 family, member A2 & 1.03 & 2.04 \\
\hline \multicolumn{5}{|c|}{ Stress related genes } \\
\hline NM_205124 & PPP2CB & protein phosphatase 2 (formerly $2 \mathrm{~A}$ ), catalytic subunit, beta isoform & 1.33 & 2.52 \\
\hline NM_001030977 & ASNS & asparagine synthetase & 1.71 & 3.27 \\
\hline NM_204880 & ATF4 & activating transcription factor 4 (tax-responsive enhancer element B67) & 1.56 & 2.95 \\
\hline XM_001235032 & WRN & Werner syndrome & 1.34 & 2.53 \\
\hline NM_001109785 & HSP90 & heat shock protein $90 \mathrm{KDa}$ alpha & 1.07 & 2.10 \\
\hline NM_001008437 & DNAJC3 & DnaJ(HSP40)homolog, subfamily C, menber3 & 1.24 & 2.36 \\
\hline NM_205491 & HSPA5 & heat shock $70 \mathrm{kDa}$ protein 5 (glucose-regulated protein, $78 \mathrm{kDa}$ ) & 1.18 & 2.26 \\
\hline NM_204476 & SGK1 & serum/glucocorticoid regulated kinase 1 & 1.05 & 2.06 \\
\hline NM_001030943 & RIPK2 & receptor-interacting serine-threonine kinase 2 & 1.09 & 2.13 \\
\hline
\end{tabular}

*The microarry was a Affymetrix chicken genome array $X$.

${ }^{* *}$ A 2 .0-fold difference in gene expression was set as a cutoff value. 
Table 4. Information of the down-regulated genes on lipid metabolism and stress

\begin{tabular}{lllrl}
\hline \multirow{2}{*}{ Accession no. } & \multirow{2}{*}{ Gene symbol } & \multicolumn{1}{c}{ Gene function } & $\begin{array}{c}\text { Log2 } \\
\text { ratio }\end{array}$ & $\begin{array}{c}\text { Fold } \\
\text { change }\end{array}$ \\
\hline Lipid metabolism & & & -1.01 & 2.01 \\
NM_205423 & PLA2G4A & phospholipase A2, group IVA & -1.10 & 2.14 \\
XM_424400 & AGPAT6 & 1-acylglycerol-3-phosphate O-acyltransferase 6 & -1.26 & 2.39 \\
XM_419616 & AGPAT4 & 1-acylglycerol-3-phosphate O-acyltransferase 4 & -4.59 & 24.09 \\
NM_001006141 & SUCLG2 & succinate-CoA ligase, GDP-forming, beta subunit & -1.08 & 2.12 \\
NM_001006578 & OXCT1 & 3-oxoacid CoA transferase 1 & -1.08 & 2.12 \\
XM_418909 & ALDH5A1 & aldehyde dehydrogenase 5 family, member A1 & -1.10 \\
NM_001006547 & BDH1 & 3-hydroxybutyrate dehydrogenase, type 1 & 2.14 \\
NM_001001613 & CD74 & CD74 molecule, major histocompatibility complex, class II invariant chain & -1.45 & 2.74 \\
NM_204890 & SCD & stearoyl-CoA desaturase (delta-9-desaturase) & -1.78 & 3.44 \\
NM_001031430 & SYK & spleen tyrosine kinase & -1.85 & 3.60 \\
XM_415754 & HSD3B7 & hydroxy-delta-5-steroid dehydrogenase, 3 beta- and steroid delta-isomerase & 7 & -1.18 \\
XM_422670 & PIGX & Phosphatidylinositol glycan anchor biosynthesis, class X & 2.27 \\
NM_205308 & FABP5 & fatty acid binding protein 5 & -1.65 & 3.14 \\
NM_001006346 & FABP7 & fatty acid binding protein 7, brain & -1.07 & 2.10 \\
Stress related gen & & & -1.19 & 2.29 \\
XM_419931 & PXDN & Peroxidasin homolog (Drosophila) & \\
NM_001012930 & BCL6 & B-cell CLL/lymphoma 6 (zinc finger protein 51) & -1.09 & 2.12 \\
XM_417715 & EYA3 & eyes absent homolog 3 (Drosophila) & -1.09 & 2.14 \\
NM_001085439 & SHFM1 & split hand/foot malformation (ectrodactyly) type 1 & -1.12 & 2.18 \\
NM_205149 & IFNG & interferon, gamma & -1.61 & 3.05 \\
NM_204304 & PDCD4 & programmed cell death 4 (neoplastic transformation inhibitor) & -2.41 & 5.32 \\
NM_001031430 & SYK & spleen tyrosine kinase & -1.03 & 2.05 \\
\hline
\end{tabular}

*The microarry was a Affymetrix chicken genome array $X$.

${ }^{* *}$ A 2 .0-fold difference in gene expression was set as a cutoff value.

소가 관찰 되었다. 장기적 고온스트레스에 노출 $\left(32-34^{\circ} \mathrm{C}\right)$ 된 육 계의 골격근에서는 지방산 산화관련 효소의 활성이 낮아진 후 적응기간을 거쳐 회복되면서 산화적 손상을 감소시킨다는 보고가 있었으며[1], 단시간 열에 노출 $\left(35^{\circ} \mathrm{C}, 3 \mathrm{hr}\right)$ 된 육계의 간에서는 일시적으로 reactive oxygn species (ROS) 생성과 지방산과산화가 증가하였으나 이후 점진적으로 정상적인 상 태로 회복된다고 하였다[28]. 육계에 인위적으로 스트레스를 유발하기 위하여 2주간 corticosterone을 첨가하여 급여한 시 험에서 ROS 및 지방산과산화 등에 의한 산화적 스트레스가 유발되지만 투여 후 3일이 지나면 스트레스에 적응하기 시작 하여 추가적인 산화적 스트레스로부터 회복 된다고 하였다 [17]. 장시간 고온 노출 $\left(34^{\circ} \mathrm{C}, 14\right.$ 일)한 육계의 근육에서 $\mathrm{ROS}$ 의 생성을 시간대별로 관찰한 결과 노출 이후 1 주일까지는 스트 레스에 대한 ROS의 증가가 유발되지만 이후 점진적으로 감소 하여 14 일 후에는 정상적인 수준으로 회복되는 것으로 보아 장기간 스트레스 노출은 동물이 일정기간 적응기간을 거쳐 회복된다고 보고하였다[2]. 고온 스트레스에 노출 $\left(33^{\circ} \mathrm{C}, 3\right.$ 주 $)$ 한 육계의 간과 근육에서 마이크로어레이를 이용하여 유전체 의 전사체발현 분석을 하여, 근육에서 최소한 110 개의 유전자 가 스트레스에 의해 증감을 보였다고 보고한 바 있으나[15], 닭에서 열 스트레스와 연관된 기작을 이해하는데 충분한 자료
를 제공하지 못하였다. AGPAT4은 포유동물에서는 인지질의 생합성에 관여하는 것으로 알려져 있고, AGPAT6은 포유동물 의 유선세포에서 유지방합성에 중요한 것으로 보고되었으나 [3], 조류에서는 그 기능이 알려진 바가 없다. 지금까지 알려진 것을 보면 스트레스를 받은 닭은 corticosterone의 증가와 인슐 린 과다분비로 인하여 체내에 지방축적이 증가하는 것으로 알려져 있다[7,12,29]. 육계의 간에서 밀사에 의한 스트레스 관 련 유전체 전사체의 발현에 관한보고는 현재까지 없는 실정이 다. 밀사에 의한 SCD의 발현 감소는 포화지방산에서 불포화 지방산으로 전환되는 것을 저해하는 것으로 볼 수 있으며, 이 는 닭의 체지방에 불포화 지방산의 감소로 연결된다고 볼 수 있다. 밀사와 체지방성분 변화에 대한 연구가 필요한 것으로 사료된다. 본 연구에 의하면 밀사 후 닭의 간에서는 지방을 합성하기 위한 유전자들이 활발하게 작용을 하고, 동시에 합 성된 지방산을 분해하여 에너지를 생산하기 위한 지방산의 산화도 활발하게 일어나고 있음을 볼 수 있다. 밀사는 닭에게 스트레스를 유발하고 산육 성적에도 부정적으로 나타났는데 (Table 2), 이는 근육 성장뿐만 아니라 스트레스로 인한 지방산 의 과다 분해에 의하여 지방조직내 지방의 축적이 대조구에 비하여 낮은 것으로 추정된다. 닭의 경우 간은 주요 대사의 중심 기관일 뿐만 아니라, 닭에 있어서 지방합성은 지방조직 
A

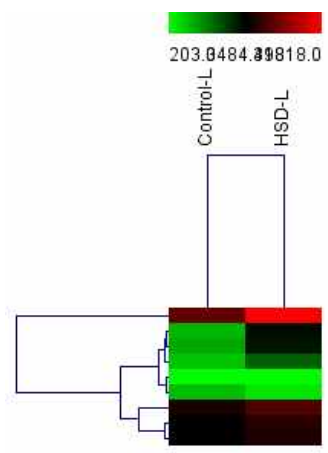

B

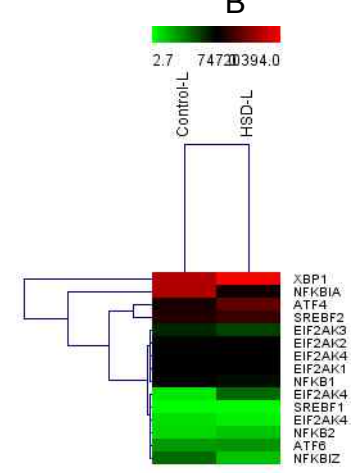

C

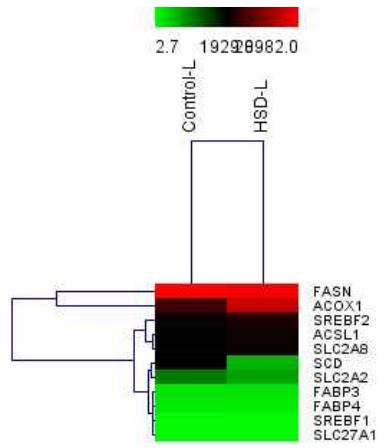

Fig. 1. Heat map generated from mRNA microarray in the liver of broiler chicken subjected to control and high stocking density (HSD). A: Stress associated gene, B: ER stress associated genes, C: Fatty acid synthesis associated genes. Expression values on top of heat map are expressed as a color code corresponding to the $\log 2$ ratio of expression values from RNA microarray data. The red and green represent up- and down-regulation of gene, respectively.

Table 5. Comparison of microarray and real-time RT-PCR analyses of some selected genes

\begin{tabular}{|c|c|c|c|c|c|c|}
\hline \multirow{3}{*}{ Genes } & \multirow{3}{*}{$\begin{array}{c}\text { Microarray } \\
\text { Fold chage* } \\
\text { (HSD/C) }\end{array}$} & \multicolumn{4}{|c|}{ Real-time RT-PCR } & \multirow{3}{*}{$p$ value ${ }^{* *}$} \\
\hline & & \multicolumn{2}{|c|}{ Control } & \multicolumn{2}{|c|}{ HSD } & \\
\hline & & $\Delta \mathrm{Ct}$ & $2^{-\Delta \Delta C t}$ & $\Delta \mathrm{Ct}$ & $2^{-\Delta \Delta C t}$ & \\
\hline HMGCR & 2.63 & $8.59 \pm 1.09$ & 1 & $4.37 \pm 1.73$ & 18.65 & 0.0027 \\
\hline HSP90a & 2.10 & $4.67 \pm 0.89$ & 1 & $2.71 \pm 1.05$ & 3.87 & 0.0489 \\
\hline HSP70 & - & $5.98 \pm 0.95$ & 1 & $6.07 \pm 1.43$ & 0.94 & 0.9370 \\
\hline DNAJA3 & 2.43 & $12.52 \pm 1.88$ & 1 & $9.45 \pm 2.01$ & 8.35 & 0.0423 \\
\hline DNAJB9 & 2.01 & $6.78 \pm 1.04$ & 1 & $6.75 \pm 1.51$ & 1.02 & 0.9764 \\
\hline ACOX1 & 2.60 & $5.34 \pm 1.21$ & 1 & $2.25 \pm 2.07$ & 8.50 & 0.0284 \\
\hline SCD & 0.29 & $6.20 \pm 1.19$ & 1 & $7.35 \pm 3.39$ & 0.45 & 0.6089 \\
\hline SREBP1 & 2.07 & $12.64 \pm 0.80$ & 1 & $13.20 \pm 0.30$ & 0.68 & 0.3186 \\
\hline FASN & 0.98 & $3.87 \pm 047$ & 1 & $3.60 \pm 0.68$ & 1.21 & 0.5990 \\
\hline FABP4 & 0.85 & $5.64 \pm 0.33$ & 1 & $7.30 \pm 0.37$ & 0.32 & 0.0044 \\
\hline XBP1 & 2.07 & $2.29 \pm 0.12$ & 1 & $1.61 \pm 0.19$ & 1.61 & 0.0060 \\
\hline ATF4 & 2.95 & $1.32 \pm 0.36$ & 1 & $0.84 \pm 0.27$ & 1.40 & 0.1367 \\
\hline
\end{tabular}

*Fold changes (HSD/C: high stocking density/control).

**Student's t-test $p$ values.

보다 간에서 더 활발하게 일어나며 지방조직에 축적되어 있는 대부분의 지방도 간이나 식이성 지방으로부터 중성지방의 형 태로 전이된 것이다[11]. 즉 지방의 합성과 분해의 균형이 어느 쪽으로 더 이동하느냐에 따라 닭의 체중에도 영향을 미칠 것 으로 보인다.

Heatmap 및 Microarray와 real-time PCR에 의한 유전자 발현 비교분석

Microarray 분석에서 확보한 자료 중 스트레스 및 지방대사 연관 유전자들을 선발하여 유전자 heatmap을 작성하였다 (Fig. 1). Heatmap은 처리별 유전자간 발현의 차이를 색으로 나타내어 쉽게 처리에 다른 반응을 확인 할 수 있었다. 또한 2-fold 미만의 유전자발현 차이로 간과해서 지나칠 수 있는 유전자들(예, SCD, FASN, FABP4)의 발현도 확인 할 수 있었
다. 스트레스 마커 유전자들인 HMGCR과 HSP90 (Fig. 1A) 등과 ER stress의 마커유전자인 XBP1, ATF4, HSPA5 (Fig. 1A, 1B) 등이 대조구에 비하여 붉은 색에 더 가깝게 표지되어 유전 자의 발현이 증가함을 보여 주었다. 지방대사 연관 유전자들 인 SREBP1과 ACOX1 등은 고밀도 사양체계에서 발현의 증가 를 보였으며, $\mathrm{FABP} 4$ 과 FASN 등은 처리에 큰 변화가 없음을 보여 주었다(Fig. 1C). 유전자 발현을 microarray로 분석한 다 음 일부 유전자들을 선택하여 real-time PCR을 실시하여 microarray 결과와 비교분석 하였다(Table 5). 대체적으로 microarray의 결과와 real-time $\mathrm{PCR}$ 의 결과는 발현정도의 차이는 있었지만 비슷한 경향을 보였다. 다만 SREBP1의 경우 microarray 결과와 real-time PCR의 결과가 상반된 결과를 보였다. HSP70은 microarry에서 발현이 확인되지 않았지만 real-time $\mathrm{PCR}$ 에서는 처리구간에 차이가 없는 것으로 나타났다. 마이크 
로어레이와 real-time PCR에서 제시된 바와 같이 $\mathrm{HMGCR}$ 과 $\mathrm{HSP} 90$ 은 밀사 스트레스에 민감하게 반응하는 것으로 나타났 으며, 본 연구자들에 의해 닭의 스트레스 마커인자로 보고된 바 있다[27]. 본 연구에서 확인한 바와 같이 XBP1과 HSPA5 또한 닭의 ER스트레스의 주요 마커인자로서 활용할 수 있을 것으로 사료된다.

결론적으로 본 연구는 닭의 주요 대사기관인 간에서 밀사에 의한 스트레스가 지방합성과 지방산 분해에 영향을 미치고 있음을 보여 주었다. 밀사에 의한 사육방식은 외적으로 증체 량 및 사료효율 등의 사양성적에도 영향을 미치지만, 동물의 분자 수준(DNA), 세포 수준(ER stress), 면역체계(스트레스)에 도 불리한 환경을 제공할 수 있음을 보여 주었다. 따라서 닭의 사양관리에서 사육밀도를 적절한 수준이하로 줄여 스트레스 를 최소화 시키는 것이 좋을 것으로 사료된다.

\section{감사의 글}

이 논문은 농촌진흥청 차세대바이오그린 21사업(과제번호: PJ007981)의 지원과 경남과학기술대학교 기성회연구비(2012) 지원에 의하여 연구되었습니다.

\section{References}

1. Azad, M. A., Kikusato, M., Maekawa, T., Shirakawa, H. and Toyomizu, M. 2010. Metabolic characteristics and oxidative damage to skeletal muscle in broiler chickens exposed to chronic heat stress. Comp. Biochem Physiol. A Mol. Integr. Physiol. 155, 401-406.

2. Azad, M. A., Kikusato, M., Sudo, S., Amo, T. and Toyomizu, M. 2010. Time course of ROS production in skeletal muscle mitochondria from chronic heat-exposed broiler chicken. Comp. Biochem. Physiol. A Mol. Integr. Physiol. 157, 266-271.

3. Beigneux, A. P., Vergnes, L., Qiao, X., Quatela, S., Davis, R., Watkins, S. M., Coleman, R. A., Walzem, R. L., Philips, M., Reu,e K. and Young, S. G. 2006. Agpat6-a novel lipid biosynthetic gene required for triacylglycerol production in mammary epithelium. J. Lipid Res. 47, 734-744.

4. Bell, M. E., Bhatnagar, S., Liang, J., Soriano, L., Nagy, T. R. and Dallman, M. F. 2000. Voluntary sucrose ingestion, like corticosterone replacement, prevents the metabolic deficits of adrenalectomy. J. Neuroendocrinol. 12, 461-470.

5. Beloor, J., Kang, H. K., Kim, Y. J., Subramani, V. K., Jang, I. S., Sohn, S. H. and Moon, Y. S. 2010. The effect of stocking density on stress related gene sand telomeric length in broiler chickens. Asian-Auat. J. Anim Sci. 23, 437-443.

6. Borradaile, N. M., Han, X., Harp, J. D., Gale, S. E., Ory, D. S. and Schaffer, J. E. 2006. Disruption of endoplasmic reticulum structure and integrity in lipotoxic cell death. $J$. Lipid Res. 47, 2726-2737.

7. Cai, Y., Song, Z., Zhang, X., Wang, X., Jiao, H. and Lin, H. 2009. Increased de novo lipogenesis in liver contributes to the augmented fat deposition in dexamethasone exposed broiler chickens (Gallus gallus domesticus). Comp. Biochem Physiol. C Toxicol. Pharmacol. 150, 164-169.

8. Cnop, M., Foufelle, F. and Velloso, L. A. 2012. Endoplasmic reticulum stress, obesity and diabetes. Trends Mol. Med 18, 59-68.

9. Dong, H., Lin, H., Jiao, H. C., Song, Z. G., Zhao, J. P. and Jiang, K. J. 2007. Altered development and protein metabolism in skeletal muscles of broiler chickens (Gallus gallus domesticus) by corticosterone. Comp. Biochem Physiol. A Mol. Integr. Physiol. 147, 189-195.

10. Gornati, R., Papis, E., Rimoldi, S., Chini, V., Terova, G., Prati, M., Saroglia, M. and Bernardini, G. 2005. Molecular markers for animal biotechnology: sea bass (Dicentrarchus labrax, L.) HMG-CoA reductase mRNA. Gene 344, 299-305.

11. Griffin, H.cD. and Hermier, D. 1988. Plasma lipoprotein metabolism and fattening on poultry. In Leclercq, B. and Whitehead, C. C. (eds.), pp. 175-201, Leanness in Domestic Birds. Butterworths, London, U.K.

12. Jiang, K. J., Jiao, H. C., Song, Z. G., Yuan, L., Zhao, J. P. and Lin, H. 2008. Corticosterone administration and dietary glucose supplementation enhance fat accumulation in broiler chickens. Br. Poult. Sci. 49, 625-631.

13. Kang, M., Ahn, H. S., Lee, J. Y., Matsuhashi, S. and Park, W, Y. 2002. Up-regulation of PDCD4 in senescent human diploid fibroblasts. Biochem Biophys. Res. Comm 293, 617621.

14. Kong, B. W., Song, J. J., Lee, J. Y., Hargis, B. M., Wing, T., Lassiter, K. and Bottje, W. 2011. Gene expression in breast muscle associated with feed efficiency in a single male broiler line using a chicken $44 \mathrm{~K}$ oligo microarray. I. Top differentially expressed genes. Poult. Sci. 90, 2535-2547.

15. Li, C., Wang, X., Wang, G., Li, N. and Wu, C. 2011. Expression analysis of global gene response to chronic heat exposure in broiler chickens (Gallus gallus) reveals new reactive genes. Poult. Sci. 90, 1028-1036.

16. Lin, H., Sui, S. J., Jiao, H. C., Buyse, J. and Decuypere, E. 2006. Impaired development of broiler chickens by stress mimicked by corticosterone exposure. Comp. Biochem Physiol. A Mol. Integr. Physiol. 143, 400-405.

17. Lin, H., Decuypere, E. and Buyse, J. 2004. Oxidative stress induced by corticosterone administration in broiler chickens (Gallus gallus domesticus) 1. Chronic exposure. Comp. Biochem Physiol. B Biochem Mol. Biol. 139, 737-744.

18. Livak, K. J. and Schmittgen, T. D. 2001. Analysis of relative gene expression data using real-time quantitative PCR and the 2(-Delta Delta C(T)) method. Methods 25, 402-408.

19. Lu, Q., Wen, J. and Zhang, H. 2007. Effect of chronic heat exposure on fat deposition and meat quality in two genetic types of chicken. Poult Sci. 86, 1059-1064.

20. Matteri, R. L., Carroll, J. A. and Dryer, C. J. 2000. Neuroendocrine responses to stress. In Moberg, G. P. and Mench, J. A. (eds.), pp. 43-76, The biology of animal stress. $\mathrm{CAB}$ International, Wallingford.

21. Rebuffé-Scrive, M., Walsh, U. A., McEwen, B. and Rodin, J. 1992. Effect of chronic stress and exogenous glucocorti- 
coids on regional fat distribution and metabolism. Physiol. Behav. 52, 583-590.

22. SAS. 1996. User's Guide: Statistics Version 6.12 Ed. SAS Inst., Inc., Cary, NC.

23. Schoenborn, J. R. and Wilson, C. B. 2007. Regulation of interferon-gamma during innate and adaptive immune responses. Adv. Immunol. 96, 41-101.

24. Sharma, N. K., Das, S. K., Mondal, A. K., Hackney, O, G., Chu, W. S., Kern, P. A., Rasouli, N., Spencer, H. J., Yao-Borengasser, A. and Elbein, S. C. 2008. Endoplasmic reticulum stress markers are associated with obesity in nondiabetic subjects. J. Clin. Endocrinol. Metab. 93, 4532-4541.

25. Sherlock, L., Wathes, C. M., Cheng, Z. and Wathes, D. C. 2012. Differential hepatic gene expression in the broiler chicken in response to the combined stressors of food withdrawal, catching and transport at the end of production. Stress 15, 293-305.

26. Singh, P., Marikkannu, R., Bitomsky, N. and Klempnauer, K. H. 2009. Disruption of the Pdcd4 tumor suppressor gene in chicken DT40 cells reveals its role in the DNA-damage response. Oncogene 28, 3758-3764.

27. Sohn, S. H., Subramani, V. K., Moon, Y. S. and Jang, I. S. 2012. Telomeric DNA quantity, DNA damage, and heat shock protein gene expression as physiological stress markers in chickens. Poult Sci. 91, 829-836.

28. Yang, L., Tan, G. Y., Fu, Y. Q., Feng, J. H. and Zhang, M. H. 2010. Effects of acute heat stress and subsequent stress removal on function of hepatic mitochondrial respiration, ROS production and lipid peroxidation in broiler chickens. Comp. Biochem Physiol. C Toxicol. Pharmacol. 151, 204-208.

29. Yuan, L., Lin, H., Jiang, K. J., Jiao, H. C. and Song, Z. G. 2008. Corticosterone administration and high-energy feed results in enhanced fat accumulation and insulin resistance in broiler chickens. Br. Poult Sci. 49, 487-495.

30. Zager, R. A. and Johnson, A. 2001. Renal cortical cholesterol accumulation is an integral component of the systemic stress response. Kidney Int. 60, 2299-2310.

\section{초록 : 닭의 고밀도 사양체계가 스트레스 및 지방대사 연관 유전자 발현에 미치는 영향 \\ 안영숙 · 박정근 · 장인석 · 손시환 · 문양수* \\ (경남과학기술대학교 동물생명과학과)}

본 연구는 육계에서 고밀도 사양체계가 간의 지놈 전사체, 특히 스트레스 및 지방대사 연관 유전자들의 발현에 어떤 영향을 미치는지 알아보기 위하여 실시하였다. 공시된 시험동물의 대조군 사육밀도는 $495 \mathrm{~cm}^{2} /$ 수, 고밀도군 은 $245 \mathrm{~cm}^{2} /$ 수를 35 일령까지 유지하였다. 대조구와 비교하여 고밀도 사양 육계에서 체중, 증체량, 사료섭취량이 유의적 $(p<0.05)$ 으로 감소되는 것으로 나타났다. 폐사율은 고밀도군에서 $15.7 \%$ 로서 대조군 $(3.7 \%)$ 에 비해 폐사율이 4.2배 높았다. 육계의 사육밀도에 따른 스트레스관련 유전자 HMGCR, HSP90a, HSPA5 (GRP78/Bip), DNAJC3, ATF4 등의 발현이 증가하였으며, interferon- $\gamma, \mathrm{PDCD} 4$ 등의 발현은 감소하였다. Endoplasmic reticulum (ER) stress 관련 HSPA5 (GRP78/Bip), DNAJC3 그리고 ATF4은 유전자들은 고밀도 사양계에서 유전자의 발현이 2-3 배 증가함을 보였다. 고밀도 사양은 지방산 합성에 관여하는 효소들(ACSL5, TMEM195, ELOVL6)의 유전자 발현 증가와 지방산산화(ß-oxidatin)에 관여하는 효소들(ACAA1, ACOX1, EHHADH, LOC423347, CPT1A)의 RNA 발 현 증가를 유도하였다. 본 연구는 밀사에 의한 스트레스가 닭의 간에서 지방을 합성하기 위한 유전자들의 발현 을 증가시키고, 합성된 지방산을 분해하여 에너지를 생산하기 위한 지방산의 산화도 높게 유지하고 있음을 보여 주었다. 닭의 주요 지방대사기관인 간에서 외부적 환경인자(사육환경)에 의한 스트레스와 생리적 대사(지방대사 및 소포체 스트레스)가 서로 밀접한 관계가 있음을 분자생물학적 수준에서 확인하였다. 따라서 스트레스저감 사 육환경제공 및 친환경 사육방법 도입 등 동물복지를 고려한 가금사양체계가 필요한 것으로 사료된다. 